\title{
Technical Efficiency of Lampai Kuning Rice in Sijunjung, West Sumatra
}

\author{
Hasnah $^{a *}$ and Riva Hendriani ${ }^{b}$ \\ ${ }^{a}$ Faculty of Agriculture, Universitas Andalas, Kampus UNAND Limau Manis, Padang, West Sumatra 25163, Indonesia \\ ${ }^{b}$ Department of Agribusiness, Payakumbuh Agriculture Polytechnic, Jln. Raya Negara Km 7 Tanjung Pati, Koto Tuo, \\ Harau, Lima Puluh Kota Regency, West Sumatra 26271, Indonesia
}

\section{ARTICLE INFO}

\section{Article history:}

Received 30 May 2018

Revised form received 25 September 2018

Accepted 06 October 2018

\section{Keywords:}

Lampai Kuning rice, Efficiency,

Stochastic frontier

\section{A B S T R A C T}

This study aims to assess the performance of farming practices of Lampai Kuning rice as an improved variety. Data were collected using survey method that relied upon primary data generated during the $2016 / 2017$ production season. Data were collected through the use of a set of structured questionnaire administered on thirty farmers in Nagari Aie Angek, Sijunjung Regency. Stata version 12 was used to test the stochastic frontier model to measure the efficiency of Lampai Kuning rice.The results showed that the use of manure and Urea had negative effect on the Lampai Kuning rice, while the use of NPK had positive effect. The level of technical efficiency of Lampai Kuning rice was very low at the 0,55 level. The study reveals that large land size led to high Lampai Kuning rice production. Farmers could double their rice production by using factor of production appropriately. 


\section{Introduction}

Rice is a strategic food product in Indonesia, because rice is the staple food of the Indonesian community. The government must maintain the availability of rice because it can affect national food security. The amount of demand for rice will continue to increase along with population growth, but this will be a problem if there is a gap between the amount of availability and demand for rice. Therefore, efforts to increase rice production are required to overcome these gaps.

Seed varieties are one of the important technology components that have a major contribution in increasing the production and income of rice farmers. Superior varieties are one of the technologies that play an important role in increasing national rice production, among others, reflected in the achievement of rice self-sufficiency in 2007.

Lampai Kuning rice is one of the leading rice varieties in Sijunjung among three other superior varieties (Junjung, Cisokan, and Batang Piaman). In 2014 its variety was released as a national superior variety by the Agricultural Technology Study Center of Sijunjung Regency. This variety has advantages such as high rice productivity which can reach 6.58 tons / ha, adaptation to medium to low elevation, productive tillers reaching 21.78 stems / clump, good quality in terms of white in colour and nice smell that are preferred by local community. Lampai Kuning rice was initially developed in Sijunjung Regency. As it has a nice taste, it was spread to the nearest regency such as Dharmasraya.

As improved variety can increase production that in turn to increase farmers' income, a good farming practices need to be employed. Thus, it is required to identify factors affecting productivity of Lampai Kuning rice in order to achieve its optimal production.
This study aims to: (1) analyse the level of technical efficiency of Lampai Kuning rice farming, (2) to assess the effects of selected factors on technical inefficiency Lampai Kuning rice farming.

\section{Research Methods}

This study was conducted in Nagari Aie Angek, as a central location of Lampai Kuning seed development in Sijunjung Sub-District, Sijunjung Regency, West Sumatra. A total of 30 respondent farmers were involved in the study and selected using the simple random sampling method.

The variables observed in this study were: (1) the production of Lampai Kuning rice expressed in $\mathrm{kg} / \mathrm{ha}$ ), (2) total seed used ( $\mathrm{kg} / \mathrm{ha}$ ), (3) total fertilizer used (kg / ha), (4) quantity of chemical used for pest and diseases management (unit / ha), (5) total labor used (mandays / ha), (6) land area (ha), (7) educational attainment of farmers, (8) age of farmers, and (9) years of experience in cultivating rice.

This study uses the stochastic frontier production function developed by Battese and Coelli (1995), where non-negative technical inefficiency effects are assumed to be functions of economic variables. Stochastic frontier production function is defined as:

$$
Y_{i}=\mathrm{f}\left(x_{i k} ; \beta_{k}\right) \exp \left(V_{i}-U_{i}\right)
$$

Where:

$\mathrm{Yi}$ is the production of Lampai Kuning rice in $\mathrm{kg}$ /ha;

$\mathrm{F}(\mathrm{x} ; \beta)$ is a Cobb-Douglas production function of vector $\mathrm{x}$ (quantity of production input used, including seeds, fertilizer, pesticides, herbicides, and labour);

Vector $\beta$ (unknown parameter); 
$\mathrm{V}$ is random errors that are assumed to be independent and identically distributed (i.i.d.) $\mathrm{N}(0$, $\left.\sigma_{\mathrm{v}}^{2}\right)$;

$\mathrm{U}$ is a non-negative random variables associated with the technical inefficiency of production, which is assumed i.i.d. So that $U$ is obtained by truncation at zero from the normal distribution with mean, $\mathrm{z} \delta$ , and variance $\sigma_{\mathrm{u}}^{2}$;

$\mathrm{Z}$ is a vector $(1 \mathrm{x} \mathrm{m})$ of free variables (land area, educational attainment, age of farmers, and years of experience in cultivating rice) associated with technical inefficiency of production;

$\delta$ is the vector $(\mathrm{m} \times 1)$ of the unknown coefficients.

Technical inefficiency effects, $U$, is defined as:

$$
U_{i}=z_{i} \delta+W_{i} .
$$

The stochastic frontier model for Lampai Kuning Rice uses cross-sectional data, hence it is assumed time-invariant. The parameters of the stochastic frontier and the model for technical inefficiency effects are estimated simultaneously using the maximum likelihood method of Stata 12 computer program. The model in this study used Battese and Corra (1977) parameterization where:

$$
\begin{aligned}
& \sigma^{2}=\sigma_{v}^{2}+\sigma_{u}^{2} \\
& \gamma=\sigma_{u}^{2} /\left(\sigma_{v}^{2}+\sigma_{u}^{2}\right) .
\end{aligned}
$$

The parameter $\gamma$ must be between 0 and 1 . This parameter allows us to obtain a good starting value for $\gamma$, for use in the iterative maximization process involving the Davidon-Fletcher-Powell algorithm (Coelli, 1996).

\section{Results and Discussions}

\section{Profile of research site}

Nagari Aie Angek is located at $160 \mathrm{~km}$ above sea level with a temperature of $30^{\circ} \mathrm{C}-36^{\circ} \mathrm{C}$ and has an average rainfall of $207.80 \mathrm{~mm}$. Land area in Nagari Aie Angek is predominantly occupied by forest (64\%), followed by settlements and tourist or sports areas. Rice field is relatively small area $(4.87 \%)$. However, rice is the main crop cultivated in this village and the main source of income for $70 \%$ population.

Nagari Aie Angek has adequate transportation and infrastructure that enable farmers to get access to their farm and sell agricultural products. Availability of few facilities Sijunjung Sub-district such BRI bank, input suppliers can support agricultural activities.

\section{Profile of respondents}

There were 30 farmers of Lampai Kuning rice interviewed in this study. All of them are at productive age ( $32-60$ years old). At this age group, farmers keen to get high income that encourage them to do farm practices well.

More than $70 \%$ of farmers have low level of education (Table 1). This condition is believed to hinder their capacity to adopt technology and manage farms. However, they get full access to farm land because all farmers grow Lampai Kuning rice on their owned land.

Most farmers have extensive experience on Lampai Kuning Rice cultivation. In addition to formal education that can increase knowledge and improve skills, the experience of farming also determines the farmers' capacity to take into account the risks that may arise.

Majority of farmers (87\%) come from small family. This indicate that only few people need to be supported by family income that leads to farmer's welfare. However, they only have small piece of land with land size of less than 1 ha that constrain them to get high income. 
Table 1. Profile of respondents

\begin{tabular}{lc}
\hline \multicolumn{1}{c}{ Description } & $\begin{array}{c}\text { Percentage of } \\
\text { respondents } \\
(\mathrm{N}=30)\end{array}$ \\
\hline $\begin{array}{l}\text { Education } \\
\text { a. Primary school } \\
\text { b. Junior high school }\end{array}$ & 73,33 \\
& 26,67 \\
Land status: owned land & 100 \\
Farming experience & \\
(years) & 26,67 \\
a. $1-9$ & 30,00 \\
b. 10-19 & 43,33 \\
c. $20-30$ & \\
& \\
Household size (person) & \\
a. 1 - 3 & 86,67 \\
b. $4-6$ & 13,33 \\
& \\
Land size & \\
a. $<0,5$ ha & \\
b. $0,5-1,0$ ha & 66,67 \\
\end{tabular}

The use of input on Lampai Kuning Rice farming

Farmers planted certified seed of Lampai Kuning rice that come from Lampai Kuning rice seed breeding located in Nagari Aie Angek. Then, rice is commonly stored aside to be used in the next planting season. The price of the Lampai Kuning rice seed is Rp. 10,000 / kg. The study reveals that famers use seed about $77.11 \mathrm{~kg} / \mathrm{ha}$. The amount of seed used is higher than recommended amount by Department of Food and Plantation of Sijunjung (30 kg/ha).

Fertilizing is an important activity in rice farming to get optimal results. Fertilizers used by farmers were manure and inorganic fertilizers. The types of inorganic fertilizers used by sample farmers were Urea, NPK Phonska and SP-36. The price of Urea is Rp. 3,000/kg, NPK Rp. 3,500/kg, and SP-36 Rp. 3,500/kg.

Manure and Urea were the main fertilizer used by farmers, while small amount of SP-36 was applied (Table 2). The amount of manure used per hectare per planting season was $229.90 \mathrm{~kg}$, while SP36 was $8.38 \mathrm{~kg}$.

Only a few farmers used pesticides to control pests and diseases. The type of pesticide used were Ukrater and Fastak. The average cost of pesticides per hectare was Rp.19,121/ ha.

Tabel 2. Average of Production and the Use of Input per Hectare per Year

\begin{tabular}{lr}
\hline \multicolumn{1}{c}{ Description } & \multicolumn{1}{c}{ Total } \\
\hline Production $(\mathrm{kg})$ & $3,790.38$ \\
Manure $(\mathrm{kg})$ & 229.90 \\
Urea $(\mathrm{kg})$ & 120.19 \\
NPK Phonska $(\mathrm{kg})$ & 114.74 \\
SP - 36 (kg) & 8.38 \\
Cost of pesticide $(\mathrm{Rp})$ & $19,121.00$ \\
Labour (man days) & 97.00 \\
\hline
\end{tabular}

Labour is needed for every stage of rice farming, from land processing, planting, maintenance to harvesting. The workforce consists of male and female labour both from within the family and outside the family. The average of labour used was 97 man days/ha.

The average production of Lampai Kuning varieties per hectare was $3,790.38 \mathrm{Kg} / \mathrm{Ha}$. The highest production was $4,390.91 \mathrm{~kg} / \mathrm{ha}$ and the lowest production was $3,415.50 \mathrm{Kg} / \mathrm{Ha}$.

The production of Lampai Kuning rice in Nagari Aie Angek is still relatively low. The average production can 6.58 tons/ha. This is far from the expected production. The low production of rice produced by the sample farmers is caused by technical culture treatments that are not carried out optimally, especially in the case of small amounts of fertilizer used due to lack of capital, poorly regulated water conditions and infertile land.

Price received by farmers fluctuated. The price of Lampai Kuning variety is Rp. 10,000 per bushel, 
equivalent to Rp. $6,400 / \mathrm{Kg}$ of rice grain, if it is calculated 1 bushel to equal to $1.5 \mathrm{~kg}$ of rice grain. The price of the Lampai Kuning grain is indeed quite higher than the price of other varieties of grain such as Banang Pulau grain with the price of Rp.8,000/bushel.

The results showed that three out of six variables have significant effect on Lampai Kuning rice production at $5 \%$ confidence level (Table 3 ). The use of manure and Urea has a negative effect on yields. Reducing the use of these two production inputs will increase Lampai Kuning Rice yields. One percent decrease in the use manure and Urea can increase rice production by 0.07 percent and 0.03 percent, respectively.

NPK use has a positive correlation to the production of Lampai Kuning Rice. Increased use of NPK of 1 percent will increase Lampai Kuning Rice yield of 0.05 percent.

The use labour has positive effect on Lampai Kuning Rice production. Increasing in the use of labour can increase the rice production. On average, rice output increases by 0.03 percent for a 1-percent increase in labour used.

Table 3. Maximum Likelihood Estimation of Cobb Douglas Function at Lampai Kuning Rice Farming

\begin{tabular}{lcc}
\hline \multicolumn{1}{c}{ Variable } & Coefficient & z-value \\
\hline Constant & $36.15^{*}$ & 28.41 \\
ln manure & $-0.07^{*}$ & -3.22 \\
ln Urea & $-0.03^{*}$ & -2.36 \\
ln NPK & $0.05^{*}$ & 3.23 \\
ln SP-36 & 0.02 & 0.79 \\
ln Pesticide & -0.002 & -0.18 \\
ln labour & $0.03^{*}$ & 3.68 \\
\hline
\end{tabular}

*significant at $\alpha=0.05$

Our results is quite different from study by Mariano, Villano, and Fleming (2011). They found that production input have positive significant effect on rice production on all studied areas.
The level of technical efficiency of Lampai Kuning Rice farming is still low at 0.55 on average with a range of $0.02-0.97$. This means that there is still a potential to increase Lampai Kuning Rice production by increasing the efficiency of production input used. Most farmers (53\%) had a technical efficiency level smaller than 0.623 (Figure 1). The mean technical efficiency level of rice production in the Philippines (74\%) (Mariano et al., 2011) is higher than technical efficiency level of rice production this study. This indicates that the management practices by Philippines farmers is better than those in this study.

Figure 1. Level of Technical Efficiency of Lampai Kuning Rice

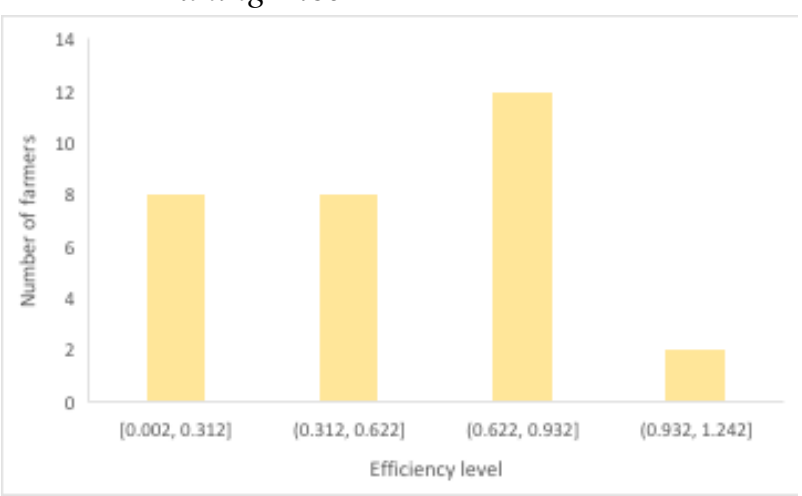

Based on the research findings, land size has significant effect on efficiency level (Table 4). The negative sign of coefficient on land size means large land size is more efficient than small land size.

Tabel 4. Maximum Likelihood Estimate of Inefficiency Model

\begin{tabular}{|l|c|c|}
\hline \multicolumn{1}{|c|}{ Variable } & Coefficient & Z-value \\
\hline Land size & -7.84 & $-1.73^{*}$ \\
\hline Age & 0.21 & 1.03 \\
\hline Education & 2.23 & 1.25 \\
\hline Household size & -1.52 & -0.96 \\
\hline Experience & -0.03 & -0.20 \\
\hline Constant & -5.53 & -0.80 \\
\hline
\end{tabular}

*significant at $\alpha=0.10$ 
None of farmers' characteristics variables are significant in inefficiency model in this study. While the results of other studies varies. Amos (2007) dan Mariano et al.(2011) found that the age variable and the number of household member have a positive sign. This means that older farmers tend to be more inefficient. The negative coefficient of education and farming experience suggest that more formal education and more experience are associated with higher technical efficiency in rice farming (Mariano et al., 2011). This figure is contradict to finding by Hasnah, Fleming, and Coelli (2004) where famers with lower educational level tend to be more efficient on oil palm production.

\section{Conclusion}

The study results can be concluded that:

a. Lampai Kuning Rice yields at farm level is much lower than estimated, which was 3,790.38 $\mathrm{kg}$ per hectare per planting season.

b. Factors that affect Lampai Kuning Rice production significantly were the use of manure, Urea and NPK.

c. The technical efficiency level of Lampai Kuning Rice farming was still low with an average of 0.55 . This means that farmers have the potential to increase the production of Lampai Kuning Rice doubled if the production factor is used appropriately.

It is suggested that farmers decrease the amount of manure and Urea use to increase their Lampai Kuning Rice production, and increase the use of NPK appropriately.

Governments can work with academics to apply the implications of this research findings, particularly, in improving farming practices to increase the production of Lampai Kuning Rice that will have an impact in increasing the income of farmers.

\section{References}

Aigner, D., Lovell, C.A.K. and Schmidt, P. 1977, 'Formulation and estimation of stochastic frontier production function models', Journal of Econometrics, 6, pp. 21-37.

Amos, T. T. (2007). An Analysis of Productivity and Technical Efficiency of Smallholder Cocoa Farmers in Nigeria. Journal of Social Sciences, 15(2), $127-133$.

Battese, G.E. 1992, 'Frontier production functions and technical efficiency: a survey of empirical applications in agricultural economics', Agricultural Economics, 7, pp. 185-208.

Battese, G.E. and Coelli, T.J. 1995, 'A model for technical inefficiency effects in a stochastic frontier production function for panel data', Empirical Economics, 20, pp. 325-332.

Battese, G.E. and Corra, G.S. 1977, 'Estimation of a production frontier model: with application to the pastoral zone of eastern Australia', Australian Journal of Agricultural Economics, 21, pp. 169-179.

Binam, J. N., Gockowski, J., and Nkamleu, G. B. (2008). Technical Efficiency and Productivity Potential Of Lampai Kuning Rice Farmers In West African Countries. The Developing Economies, 46(3), 242-263. doi: 10.1111/j.1746-1049.2008.00065.x

BPS Sumatera Barat. 2016. Sumatera Barat Dalam Angka. Padang. BPS Sumatera Barat

Coelli, T.J. 1996, ‘A guide to Frontier version 4.1: A computer program for stochastic frontier production and cost function estimation', CEPA Working Papers, 7/96, Department of Econometrics, University of New England, Armidale.

Coelli, T.J., Battese, G.E., 1996. Identification of factors which influence the technical 
inefficiency of Indian farmers. Australian Journal of Agricultural Economics 40 (2), $103-128$.

Farrell, M.J. 1957, 'The measurement of productive efficiency', Journal of the Royal Statistical Society, ser. A, 120, pp. 253-290.

Hasnah, Fleming, E., and Coelli, T. (2004).

Assessing the Performance of a Nucleus Estate and Smallholder Scheme for Oil Palm Production in West Sumatra: A Stochastic Frontier Analysis. Agricultural Systems, 79(1), 17-30.
Mariano, M. J., Villano, R., and Fleming, E. (2011). Technical Efficiency of Rice Farms in Different Agroclimatic Zones in the Philippines: An Application of a Stochastic Metafrontier Model. Asian Economic Journal, 25(3), 245 - 269. doi:10.1111/j.14678381.2011.02060.x 